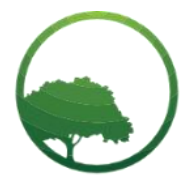

Business \& Social Science IJRBS

\section{Research in Business \& Social Science}

IJRBS VOL 10 NO 6 ISSN: 2147-4478

Available online at www.ssbfnet.com

Journal homepage: https://www.ssbfnet.com/ojs/index.php/ijrbs

\title{
An empirical investigation into organizational level antecedents of value co-destruction in Lisbon, Portugal: A hospitality sector case
}

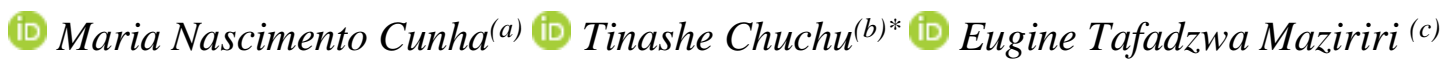 \\ (a) Adjunct professor, Department of Management Sciences, Universidade de Aveiro, Portugal \\ (b) Senior Lecturer, Marketing Division, School of Business Sciences, University of the Witwatersrand, Johannesburg, South Africa \\ ${ }^{(c)}$ Department of Business Management, Faculty of Economic and Management Sciences, University of the Free State, Bloemfontein, South Africa
}

\author{
ART ICLE INFO

\section{Article history:} \\ Received 14 August 2021 \\ Received in rev. form 17 Sep. 2021 \\ Accepted 19 Sept 2021 \\ Keywords: \\ Organization; Co-Creation; Co- \\ Destruction; Hospitality Sector; \\ Employees \\ JEL Classification: \\ E2, H8, L83, J0
}

\begin{abstract}
A B S T R A C T
In recent years, scholars have begun to dedicate their attention to destructive relationships as a critical component of organizational life. Prior research has approached it from various points of view, such as trust and partnering, project management, and relational coordination. The purpose of this research is to explore organizational level antecedents of value co-destruction in Lisbon, Portugal within the hospitality sector. The research was quantitative in nature, adopting the survey method. To measure the proposed hypotheses, a unique conceptual model was developed with leadership support, supportive organizational climate, value co-destruction, and commitment to value co-creation as constructs. Data was collected from the hospitality sector of Lisbon, Portugal where 600 responses were obtained for analysis. All participants were employees from the hospitality sector. Key findings revealed that leadership support was dominant in comparison to the other constructs based on how high it loaded as a factor. In addition, a high perception of a supportive organizational climate among service employees will result in a low occurrence of value co-destruction in their organization. Further research direction on the subject is proposed.
\end{abstract}

(C) 2021 by the authors. Licensee SSBFNET, Istanbul, Turkey. This article is an open access article distributed under the terms and conditions of the Creative Commons Attribution (CC BY) license (http://creativecommons.org/licenses/by/4.0/).

\section{Introduction}

Most service organizations particularly the hospitality sector understands the value creation capabilities of their guests and seeks to involve them in the value creation processes in order to achieve optimal performance. While value co-creation is a goal and perhaps the intended objective of many hospitality settings, interaction between frontline employees and their customers during service encounters may trigger misbehaviour incident which mostly results in co-destruction of value (Kashif \& Zarkada, 2015). The composition of service-system which includes both the customers and employees at its core suggests that the interactions between employees and customers are integral in the value creation process of service companies. Customer attitudes are central to service organizations (Maziriri, Rukuni \& Chuchu, 2020). According to Vargo and Lusch (2008), the effective management of the company resources is precursory to the quality of value created and deliver by the organization. Thus, company must effectively manage the interactions between their employees and customers to deliver cutting-edge values that beat competition. It will not be out of place to infer that as customers are integral to the co-creation of value process, they can also be key part of the journey to co-destruction of value (Echeverri, Salomonson \& Åberg, 2012).

Although service literature seems to be thorough in their investigation of value co-creation, its antecedents and consequences (Devereux \& Gallarza, 2019; Foroudi, Yu, Gupta, \& Foroudi, 2019) have the same level of research deficit in the area of value codestruction. The detriment impact of value co-destruction if unchecked is similar if quantified to the beneficial impact of value cocreation and must thus be given adequate attention in order to forestall its influence the overall service delivery and company's value propositions. Following the aforementioned reasoning, this research aimed at understanding the antecedents of value co-destruction

* Corresponding author. ORCID ID: 0000-0001-7325-8932

(C) 2021 by the authors. Hosting by SSBFNET. Peer review under responsibility of Center for Strategic Studies in Business and Finance. https://doi.org/10.20525/ijrbs.v10i6.1326 
in service organizations. Specifically, the body of literature have been made through the use of explorative research design for establishing the background for assessment of the capacity of the entire investigation. Supportive organizational climate Influences organizations' commitment to service co-creation, leaders support, organizational climate and knowledge management system on value co-destruction experiences of the company is studied. The findings of this research are that high perception of commitment to value co-creation will result in low occurrence of value co-destruction. Empirical results also showed that high perception of supportive organizational climate among service employees will result in low occurrence of value co-destruction in their organization. Finally, high level of leadership support of value co-creation in hotels will result in low occurrences of value co-destruction in the same establishment.

\section{Literature Review}

\section{Theoretical and Conceptual Background}

\section{Value co-destruction}

In the recent past, scholars have begun to dedicate their attention towards destructive relationships as a critical component of organizational life, facing it from various points of view, such as trust and partnering (Cunha 2019), project management (Kerzner, 2018), and relational coordination. The term "co-destruction" is now used in service ecosystems to describe the phenomenon in which multiple actors interact and integrate their resources to realise valuable benefits (Plé, 2017), yet their collaborations result in a decline of the well-being of at least one of these actors (Cunha, 2019). The interactive effort between service providers and their consumers often result in value creation or at the very least value proposition with the objective of value creation. However, at seldom times, these interactions result in negative outcomes (Echeverri \& Skålén, 2011). According to Plé and Chumpitaz Cáceres (2010) value co-destruction is the resulting decline in at least a component of the service system's well-being as a result of interactions between the service systems. In essence, value co-destruction is the negative outcome of a failed system interaction process (Järvi, Kähkönen, \& Torvinen, 2018). Like service failures, value co-destruction can occur at various points in the interactional processe for service delivery. Scholars have elucidated areas such as organizational incompetency (Järvi et al., 2018), lack of adequate resource (human and material) (Vafeas, Hughes, \& Hilton, 2016), inadequate communication or lack of information (Robertson, Polonsky, \& McQuilken, 2014) and so on.

Consequences of value co-destruction range from a manageable decline in well-being to more severe loss of reputation and assets such as revenue (Prior \& Marcos-Cuevas, 2016). A failed process may also result in lack of trust in future dealings and engagements thereby quenching the potentials for future value co-creation initiatives (Prior \& Marcos-Cuevas, 2016). In spite of the growing interest and significance of value co-destruction, there is a dearth of study examining the antecedents of the construct with the exception of Jarvis et al., (2018). Both studies however examined the antecedents of value co-destruction conceptually and at a broad level. This study extends both research findings by empirically investigating the organizational level antecedents of value codestruction within the hospitality settings. Thus, we explored the views of the service provides to harness valuable insights into why and how value co-destruction can be initiated from the organization viewpoint.

\section{Service dominant logic}

This paradigm of study believed that in service delivery, organizations provide the services while the users consume the created services in a dichotomous manner (Kim, Byon, \& Baek, 2019). S-D logic distinctively provides individual role of service providers and users in the resource integration process of value co-creation. Thus, S-D logic have been deemed appropriate theoretically for underpinning research focused on co-creation and co-destruction (Luo, Wong, King, Liu, \& Huang, 2019; Morosan, \& DeFranco, 2019). In conceptualising our research model, we apply S-D logic to highlight the roles of service providers in the interactional process of value co-creation. Service organizations are dependent on effective marketing strategies (Gujral, Rauzela \& Chuchu, 2016). As previous studies have noted, organization's readiness is important to facilitate their value co-creation initiatives. Thus, we examine the impact of organization's supportive climate, commitment to value creation and leadership support on value codestruction.

\section{Leadership support and value co-destruction}

Service transactions mostly occur between the internal customers and external customers of service organizations (Read, 2011). As depicted by the S-D logic, each actor in the service system uniquely contributes to the overall value proposition that is eventually delivered to the external consumers. While internal consumers are saddled with the responsibilities of service creation, they sometimes rely on information made available to them by the external consumers in forming the value offerings. Although this process may be fruitful and productive, its optimal performance is hinged on the disposition of the leadership of the service organization towards value co-creation. Employees are either given task or role to perform specific functions or are empowered to take initiatives in certain circumstances. Irrespectively of the approach or scenario in which service employees operate with, they require either directly or indirectly the support of their leaders to deliver value to their end users.

Leadership support refers to the willingness of leaders in organizations to provide the needed support to an operating process and their explicit role of giving the necessary directions for running the business (Cunha, 2019). Effective leadership is central to the success of any organization (Pamacheche, Chinomona \& Chuchu, 2016).In other words, it refers to the commitment of top managers 
to act as executive sponsors for specific projects (Cunha, 2019). Leadership support helps in building trust, helpfulness and support among employees (Hsu, Liu, Tsou \& Chen, 2018). Since the leadership role in organization involves resource allocation, organizations whose leaders support value co-creation will undoubtedly allocate resources that will enable the smooth running of value co-creation processed (Yang, 2008; Rodríguez et al., 2008). Thus, we posit that service organizations that provide leadership support for value co-creation initiatives are more likely to experience lesser cases of value co-destructions than their counterparts with more stringent views on value co-creations.

\section{Supportive organizational climate and value co-destruction}

Gu and Peng (2010) defined organizational climate as the "policies, practices, and procedures jointly perceived by members of an organization, as well as perceived reward, support, and anticipation". Organizational climate is a major distinguishing factor that differentiates organizations from one another. At individual- level, it refers to the subjective individual's psychological perception of the environment (Zhou, 2015). Employees often perceive the climate in their organization as supportive when they enjoy the backing of the organization regarding their role prescription and special strategic goals that favour the employees (Zhao, Tao \& Xiong, 2019). Scholars have also highlighted that supportive organizational climate fosters communication among employees which aid the flow of tacit knowledge in the organization (Zhao et al., 2019). Furthermore, Luthans, Youssef and Avolio (2007) alluded that felt organizational support reduces frustrations and pessimism, while Kirrane, Lennon, O'Connor, and Fu (2017) believed that a supportive climate will induce optimistic psychological outcomes, stimulates employees' psychological potentials and minimise their sense of isolation.

\section{Commitment to value co-creation and value co-destruction}

Service experience is a total package of the service ambience, service product and service delivery. Service-dominant Logic (S-D logic), as a paradigm and reaction against Goods-dominant logic, highlights the role of intangible resources (e. g. skills and knowledge) and interactions to create value (Cunha, 2019). This logic emphasises on the fact that the customer can become a cocreator of value (Cunha, 2019). Value co-creation is the process during which consumers take an active role and cocreate value together with the company (Cunha, 2019). It is concluded value co-creation helps to achieve competitive advantages (Payne \& Frow, 2013) and fulfil personalised demands (Cunha, 2019). Company s and customers receive mutual benefits of value co-creation. Company related benefits are lower prices, faster speed (Claycomb, Dröge and Germain, 2001); brand awareness, idea generation marketing insight, cost savings (Cunha, 2019); effectiveness, efficiency and increased complexity (Hoyer, Chandy, Dorotic, Krafft \& Singh, 2010). Customer-related advantages are enhanced operating efficiencies, greater service value (Chuchu, Chiliya and Chinomona, 2018; Claycomb et al., 2001); the ability to fulfil personal needs and interests (Cunha, 2019); fit with consumer needs, relationship building, engagement and satisfaction (Hoyer et al., 2010). Cunha (2019) indicates customer participation in co-creation activities results in increased interest in the company and reduced communication and new product development costs. In servicedominant logic, the inherent tendency of value co-creation is assumed as a result of the interactions between the parties. However, if value can be created in such situation, the possibility of co-destruction must also be supposed due to the interactions (Plé \& Chumpitaz Cáceres, 2010).

Marketing literature has been criticised because of focusing on positive aspect of customer engagement to date (Van Doorn, Lemon, Mittal, Nass, Pick, Pirner \& Verhoef, 2010). Plé and Chumpitaz Cáceres (2010) note "in terms of S-D logic, it would seem that the notion of value co-destruction has been rather implicit until now". Echeverri and Skålén (2011) mention both the upside and the downside of interactive value formation should be considered. They go on to convey that value co-destruction, like value co-creation, can occur when providers and customers have interactions. Likewise, Yousefian, Akamavi, Jayawardhena and Khavari (2011) indicate that customer engagement in value creation may be positive or negative. Indeed, actions such as word of mouth, blogging, online reviews and brand recommendation can be done positively or negatively. Norton, Mochon and Ariely (2012) believe there are risks when involving consumers in co-creation. Activities such as negative word of mouth (Plé \& Chumpitaz Cáceres, 2010) and negative complaining (Van Doom et al., 2010) can lead to destruction of value in organizations. Some scholars such as Cunha (2019) company the possibility of devaluation processes (e.g., value co-destruction) during customer engagement in value co-creation activities. For instance, this view is in line with Echeverri and Skålén (2011) report that there is not always value creative process in interactions between supplier and customers, rather value destructive outcomes are also possible. Like Plé \& Chumpitaz Cáceres (2010), they claim possibility of value co-destruction at the provider-customer interface. Cunha (2019) point out co-destruction of value may have negative effect on company s' profits. Customers who are disappointed of services offered by a company may have a negative engagement through negative word of mouth or writing negative reviews or blogs.

\section{The role of employee's attribution style}

The set of theoretical frameworks that underpins attribution theory were built on the assumption that everyone is a "naïve psychologist" who have been wired always to make sense of their encounters (Cunha, 2019) particular when they are faced with disappointing situations or experiences (Cunha, 2019). Attribution styles are justly established propensities of ascribing cause across a variation of circumstances (Cunha, 2019). Therefore, attribution styles can be considered as individual's trait-like tendencies to make specific forms of attributions (Cunha, 2019). It can also be viewed as degree of individual's bias in attributing cause to events (Martinko, Harvey, Sikora \& Douglas, 2011). 


\section{Theoretical model and hypotheses statements}

A model was elaborated from the literature review to meet the research purpose (Figure 1), which aims to understand the antecedents of value co-destruction. The conceptual model of this study proposes that, leadership support, supportive organizational climate and value co-destruction are the predictor variables on commitment value co-creation which is the outcome variable. based on a synthesis of the converging literature related to the research variables, a conceptual model was proposed to guide the empirical study as shown in figure 1. Visual representation facilitates an understanding of the conceptual model proposed.

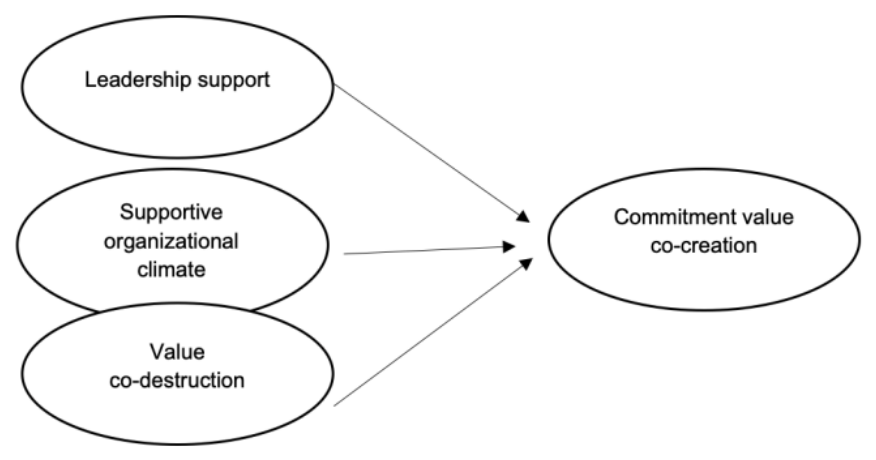

Figure 1: Theoretical model

\section{Hypotheses statements}

Given the discussion above, the following hypotheses can be stated:

H1: Leadership support is related to commitment value co-creation.

$\mathrm{H} 2$ : Supportive organizational climate is related to commitment value co-creation.

H3: Value co-destruction is related to commitment value co-creation

\section{Research and Methodology}

This study submits to the positivist paradigm since it intends to test several a priori hypotheses to determine relationships between the independent and dependent variables. The researchers selected a quantitative research approach since it increases accuracy through statistical analysis. The design justified requesting the required data related to leadership support, supportive organizational climate and value co-destruction and commitment value co-creation. In addition, the approach enables one to examine the causal relationships with the constructs used in the study.

\section{Sampling}

The study took a quantitative research approach that made use of the survey method. The sampling technique used was the convenience sampling approach due to the lack of a sampling frame. In the selection of hotels, there was no specific star status used as it would limit the sample size. An online questionnaire was used to collect data and to qualify as a participant, the respondents identified as employees of hotels located in Portugal. A total of 600 responses were obtained.

\section{The measurement instruments}

The measurement variables of leadership support, supportive organizational climate and value co-destruction and commitment value co-creation were developed based on established existing variables from past studies. Proper modifications were made to fit the current research context. Supportive organizational climate comprised of 8 items and was adapted from (Hayat \& Afshari, 2020). Leadership support was adopted from (Iqbal, Ehsan, Rizwan \& Noreen, 2014), while commitment value co-creation was taken from (Järvi, Kähkönen \& Torvinen, 2018). Last, value co-destruction was adapted from (Järvi et al., 2018). All measurement items were measured on a five-point Likert scale, and the scale indicators were affixed to a strongly disagree (1) to strongly agree (5) Likertscale continuum.

\section{Data analysis}

The gathered data were recorded on a Microsoft Excel spreadsheet after screening returned questionnaires. The data were analysed using descriptive statistics, Cronbach's alpha values and correlations, and the Statistical Package for Social Sciences (SPSS version 27.0). To test the psychometric properties of the measurement scales and hypotheses, the Analysis of Moment Structures (AMOS version 27.0) statistical software was utilised.

\section{Ethical considerations}

This research study acted in accordance with the ethical standards of academic research, for instance, all participation was voluntary and it was conducted in an anonymous manner. No personally identifying data was not collected. Participants were briefed on the 
research and provided consent prior to completion of the questionnaire. No incentives were provided to participants and they we allowed to withdraw from the study at any point.

\section{Results and Discussion}

This section presents the results of the study. Table 1, presents the distribution of workers, 53.50 (312) are part-time workers and $47.0 \%$ (288) are full-time employees.

Table 1: Part-Time vs Full Time

\begin{tabular}{lll}
\hline Monthly Income & Frequency & Percent \\
\hline Full time Hotel worker & 312 & $53,0 \%$ \\
\hline Part time Hotel worker & 288 & $47,0 \%$ \\
\hline Total & 600 & $100,0 \%$ \\
\hline
\end{tabular}

The findings displayed thus, 56.5\% (333) are male participants and 43.5\% (267) are female participants in the study.

Table 2: Gender

\begin{tabular}{lll}
\hline Gender & Frequency & Percent \\
\hline Male & 333 & $56.5 \%$ \\
\hline Female & 267 & $43.5 \%$ \\
\hline Total & 600 & $100 \%$ \\
\hline
\end{tabular}

Based on the age of the participants, $13.5 \%$ (75) are between the ages of 20-26 years, $39.0 \%$ (240) and $47.5 \%$ (285) all are between the ages of 27-33 and 34 and above respectively.

Table 3: Age

\begin{tabular}{lll}
\hline Age & Frequency & Percent \\
\hline $\mathbf{2 0 - 2 6}$ years & 75 & $13.5 \%$ \\
\hline $\mathbf{2 7 - 3 3}$ years & 240 & $39.0 \%$ \\
\hline 34 and above & 285 & $47.5 \%$ \\
\hline Total & 600 & $100 \%$ \\
\hline
\end{tabular}

Based on the monthly income of the participants, participants who earn between 500-1500 euro are 34.0\% (198) while 52.0\% (318) and $14.0 \%$ (84) earn between 1501-4000 euro and 4001 euro and above respectively.

Table 4: Monthly Income

\begin{tabular}{lll}
\hline Monthly Income & Frequency & Percent \\
\hline $\mathbf{5 0 0 - 1 5 0 0}$ euro & 198 & $34.0 \%$ \\
\hline $\mathbf{1 5 0 1 - 4 0 0 0}$ euro & 318 & $52.0 \%$ \\
\hline $\mathbf{4 0 0 1}$ euro and above & 84 & $14.0 \%$ \\
\hline Total & 600 & $100 \%$ \\
\hline
\end{tabular}

\section{Research Findings}

The results section focuses on confirmatory factor analysis (CFA), hypotheses tests performed through structural equation modelling (SEM) and discussions. A CFA is a unique type of factor analysis used to assess whether a construct's measurements are compatible with that construct's nature. The SEM method is used to evaluate interactions between latent (unobservable) variables such as dependent and independent constructs (Bagozzi \& Yi 2012).

Psychometric properties of measurement scales

The assessment of the measurement scales ' psychometric characteristics was performed through a CFA to determine the construct's reliability, validity, and model fit. Table 5 presents the outcomes of the CFA assessment. 
Table 5: Psychometric properties of measurement scales

\begin{tabular}{|c|c|c|c|c|c|c|c|c|}
\hline \multicolumn{2}{|c|}{ Research constructs } & \multirow{2}{*}{$\begin{array}{l}\text { Mean Value } \\
4.728 \\
\end{array}$} & \multirow{2}{*}{$\begin{array}{l}\text { SD } \\
1.314 \\
\end{array}$} & \multicolumn{2}{|c|}{ Cronbach's test } & \multirow{2}{*}{$\begin{array}{l}\mathbf{C R} \\
0.945\end{array}$} & \multirow{2}{*}{$\begin{array}{l}\text { AVE } \\
0.775\end{array}$} & \multirow{2}{*}{$\begin{array}{l}\text { Factor loadings } \\
0.810 \\
\end{array}$} \\
\hline \multirow{5}{*}{$\mathbf{L S}$} & LS1 & & & $\begin{array}{l}\text { Item total } \\
0.665\end{array}$ & \multirow{5}{*}{$\begin{array}{l}\text { alpha } \\
0.930\end{array}$} & & & \\
\hline & LS2 & 4.630 & 1.224 & 0.712 & & & & 0.900 \\
\hline & LS3 & 4.454 & 1.375 & 0.743 & & & & 0.899 \\
\hline & LS4 & 4.719 & 1.460 & 0.787 & & & & 0.914 \\
\hline & LS5 & 4.702 & 1.547 & 0.717 & & & & 0.874 \\
\hline \multirow[t]{8}{*}{ SOC } & SOC1 & 4.476 & 1.576 & 0.549 & \multirow[t]{8}{*}{0.850} & \multirow[t]{8}{*}{0.860} & \multirow[t]{8}{*}{0.430} & 0.603 \\
\hline & SOC2 & 4.456 & 1.654 & 0.675 & & & & 0.610 \\
\hline & SOC3 & 4.613 & 1.794 & 0.688 & & & & 0.700 \\
\hline & SOC4 & 4564 & 1.876 & 0.754 & & & & 0.736 \\
\hline & SOC5 & 5.547 & 1.880 & 0.746 & & & & 0.633 \\
\hline & SOC6 & 5.249 & 1.870 & 0.751 & & & & 0.590 \\
\hline & SOC7 & 5.542 & 1.893 & 0.753 & & & & 0.728 \\
\hline & SOC8 & 5.705 & 1.970 & 0.783 & & & & 0.649 \\
\hline \multirow[t]{5}{*}{$\mathrm{VC}$} & $\mathrm{VC} 1$ & 3.928 & 1.477 & 0.672 & \multirow[t]{5}{*}{0.890} & \multirow[t]{5}{*}{0.830} & \multirow[t]{5}{*}{0.500} & 0.874 \\
\hline & $\mathrm{VC} 2$ & 3.713 & 1.593 & 0.688 & & & & 0.838 \\
\hline & $\mathrm{VC} 3$ & 4.195 & 1.425 & 0.697 & & & & 0.543 \\
\hline & $\mathrm{VC} 4$ & 4.978 & 1.563 & 0.701 & & & & 0.679 \\
\hline & VC5 & 5.083 & 1.305 & 0.725 & & & & 0.514 \\
\hline \multirow[t]{4}{*}{ CVC } & CVC1 & 5.582 & 1.163 & 0.716 & \multirow[t]{4}{*}{0.960} & \multirow[t]{4}{*}{0.740} & \multirow[t]{4}{*}{0.420} & 0.619 \\
\hline & $\mathrm{CVC} 2$ & 5.748 & 1.075 & 0.755 & & & & 0.790 \\
\hline & CVC3 & 5.630 & 1.328 & 0.752 & & & & 0.562 \\
\hline & CVC4 & 5.456 & 1.143 & 0.799 & & & & 0.605 \\
\hline
\end{tabular}

Note: $\mathrm{LS}=$ Leadership support, $\mathrm{SOC}=$ supportive organizational climate, $\mathrm{VC}=$ value co-destruction, $\mathrm{CVC}=$ commitment value cocreation, $\mathrm{SD}=$ Standard Deviation, $\mathrm{AVE}=$ Average variance extracted, $\mathrm{CR}=$ Composite reliability.

According to Nunnally (1978), the reliability of a measure is supported if Cronbach's Alpha is 0.7 or higher. The results provided in Table 5, show that the Cronbach's Alpha value for each research variable were $\mathrm{LS}=0.930, \mathrm{SOC}=0.850, \mathrm{VC}=0.890, \mathrm{CVC}=0.960$. Cronbach's Alpha scores indicate that each construct exhibit strong internal reliability (Lee, 2009). Since the Cronbach's Alpha values of the constructs exceeded the recommended 0.70, this shows that all the variables were reasonably reliable. Table 5 shows the loading of each item on their construct. The lowest value for each respective item loading for the research constructs is 0.501 ; all the individual item loadings exceed the recommended value of 0.5 (Anderson \& Gerbing, 1988). This indicates that all the measurement instruments are acceptable and reliable, since all the individual items converged well and with more than $50 \%$ of each item's variance shared with its respective construct (Fraering \& Minor, 2006).

Composite reliabilities (CR) and average variance extracted (AVE) for each construct were also computed using the formulae proposed by Fornell and Larcker (1981, p. 22), i.e.

$$
\mathrm{CR \eta}=(\Sigma \lambda \mathrm{yi}) 2 /[(\Sigma \lambda \mathrm{yi}) 2+(\Sigma \varepsilon \mathrm{i})]
$$

Where

$\mathrm{CR} \eta=$ Composite reliability, $(\Sigma \lambda \mathrm{yi}) 2=$ Square of the summation of the factor loadings; $(\Sigma \varepsilon i)=$ Summation of error variances.

$$
\mathrm{V \eta}=\Sigma \lambda \mathrm{yi} 2 /(\Sigma \lambda \mathrm{yi} 2+\Sigma \varepsilon i)
$$

Where

$\mathrm{V} \eta=$ Average Variance Extracted (AVE); $\Sigma \lambda y i 2=$ Summation of the squared of factor loadings; $\Sigma \varepsilon i=$ Summation of error variances".

CR and AVE for each construct were also computed and assessed to determine if they met the required thresholds for reliability and validity. As per the results shown in Table 5, the lowest CR value (0.720) is well above the recommended 0.6 (Hulland, 1999), while the lowest obtained AVE value (0.420) is above the recommended 0.4 (Anderson \& Gerbing, 1988). This indicates that convergent validity was achieved, further confirming excellent internal consistency and reliability of the measurement instruments used. By and large, these results provided evidence for acceptable levels of research scale reliability" (Chinomona \& Chinomona, 2013). According to Field (2013) discriminant validity refers to items measuring different concept. Table 4 presents the results of the discriminant validity analysis. As depicted in table 6 all the correlation coefficients of this study fell below 0.70 , thereby confirming the theoretical uniqueness of each variable in this research (Field, 2013). 
Table 6: Correlation Matrix

\begin{tabular}{lllll}
\hline VARIABLES & LS & SOC & VC & CVC \\
\hline LS & 1 & - & - & - \\
\hline SOC & $0.519^{* *}$ & 1 & - & - \\
\hline VC & $0.232^{* *}$ & $0.359^{* *}$ & 1 & - \\
\hline CVC & $0.584^{* *}$ & $0.655^{* *}$ & $0.499^{* *}$ & 1 \\
\hline N & 0.5 C & & \\
\hline
\end{tabular}

Note: $\mathrm{LS}=$ Leadership support, $\mathrm{SOC}=$ supportive organizational climate, $\mathrm{VC}=$ value co-destruction, $\mathrm{CVC}=$ commitment value cocreation.

\section{Model fit analysis}

According to Anderson and Gerbing (1988), model fit analysis is a process that assesses how well the model represents the data. In this study, model fit was tested by using the following indices: Chi-square/degrees of freedom, comparative fit index (CFI), incremental fit index (IFI), Tucker-Lewis index (TLI), normative fit index (NFI), goodness of fit (GFI) and random measure of standard error approximation (RMSEA). The acceptable thresholds should be equal to or higher than 0.90 for CFI, IFI, RFI, NFI, GFI and AGFI. For Chi-square/degrees of freedom a ratio of 3:1 or less is recommended and RMSEA value should be equal to or less than 0.08 (Lysons \& Farrington, 2012). The general model fit indices for both the CFA and SEM models are presented in Table 7.

Table 7: Model fit statistics.

\begin{tabular}{|c|c|c|c|}
\hline Fit indices & $\begin{array}{l}\text { Acceptable fit } \\
\text { indices }\end{array}$ & $\begin{array}{l}\text { CFA (measurement } \\
\text { model) }\end{array}$ & $\begin{array}{l}\text { SEM (structural } \\
\text { model) }\end{array}$ \\
\hline Chi-square/degree of freedom (df) & $<3.0$ & 1.659 & 1.956 \\
\hline Incremental fit index (IFI & $>0.90$ & 0.967 & 0.951 \\
\hline Tucker-Lewis index (TLI) & $>0.90$ & 0.961 & 0.937 \\
\hline Comparative fit index (CFI) & $>0.90$ & 0.963 & 0.967 \\
\hline Normative fit index (NFI) & $>0.90$ & 0.921 & 0.945 \\
\hline Goodness of fit (GFI) & $>0.90$ & 0.914 & 0.955 \\
\hline $\begin{array}{l}\text { Root mean square error of approximation } \\
\text { (RMSEA) }\end{array}$ & $<0.08$ & 0.045 & 0.053 \\
\hline
\end{tabular}

CFA=confirmatory factor analysis; SEM=structural equation modelling

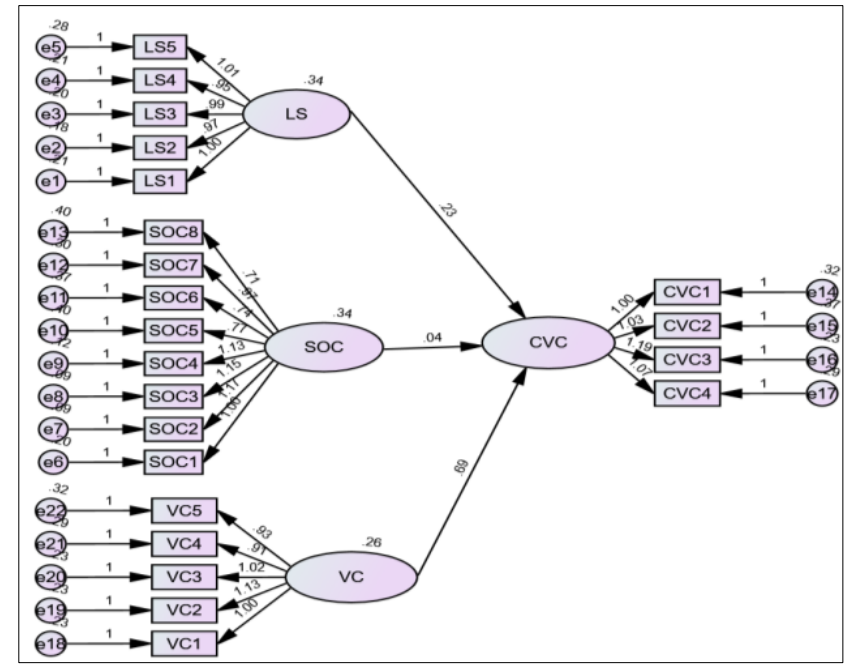

Key: Leadership support, supportive organizational climate, commitment value co-creation, value co-destruction

Figure 2: Structural model

Table 8: Hypotheses results

\begin{tabular}{lllll}
\hline Relationship & Hypotheses & P-value & Estimate & Outcome \\
\hline LS to CVC & H1 & $* * *$ & 0.23 & Supported and significant \\
\hline SOC to CVC & H2 & 0.07 & 0.04 & Supported but not significant \\
\hline VC to CVC & H3 & $* * *$ & 0.69 & Supported and significant
\end{tabular}

Key: LS: Leadership support, SOC: supportive organizational climate, CVC: commitment value co-creation, VC: value codestruction, Level of significance $p<0.05$ 
Table 8 presents the findings of the hypotheses. It is observed that all three hypotheses tested were supported. However, of the three hypotheses only one was not significant. The first hypothesis, H1 (leadership support and commitment value co-creation) was both supported and significant at the $\mathrm{p}<0.05$ level of significance indicated by $* * *$ having an estimate of 0.23 . This means that there is a relationship between leadership support and commitment value co-creation. The second hypothesis, H2 (supportive organizational climate and commitment value co-creation), was supported having an estimate of 0.04 . However, this relationship was not significant at $p<0.05$ having a $p$-value of 0.07 greater than the required 0.05 for significance. It is also important to note that this was the weakest of all hypotheses tested. The third hypothesis, H3 (value co-destruction and commitment value co-creation), was supported and significant at the $\mathrm{p}<0.05$ level of significance indicated by $* * *$ having an estimate of 0.69 . This means that there is a relationship between value co-destruction and commitment value co-creation. It is imperative to note that this was the strongest of all hypotheses tested. This following section discusses the study's contribution and conclusion thereafter.

\section{Conclusion}

The research contributed to understanding leadership support, supportive organizational climate, commitment value co-creation and value co-destruction within the hospitality sector. The research revealed that value co-destruction had a great impact on commitment value co-creation within the hospitality sector while supportive organizational climate barely contributed to commitment value cocreation within the sector.

The research explored the organizational level antecedents of value co-destruction in the Lisbon, Portugal hospitality sector. The impact of leadership support, supportive organizational climate and value co-destruction on commitment value co-creation was empirically tested. The study revealed that value co-destruction had the strongest impact on commitment value co-creation within the hospitality sector followed by value co-destruction. Last, supportive organizational climate had the weakest impact on commitment value co-creation within the sector.

The research had its fair share of limitations. First, practically, the study adopted a quantitative approach. This restricted the extent to which the participants could express themselves because they were confirmed to a Likert scale. This meant that hotel employees could have left-out a lot of key data when they provided feedback. It would be recommended that further research utilise a qualitative approach, through in-depth interviews. This would allow for more detailed feedback from the hotel employees regarding the perceptions and experiences related to the hospitality sector. Another practical suggestion is to have a wider and more geographically spread and diverse sample. This is because using only participants exposed to the same hospitality sector in the same city could have introduced some participant bias into the study. As far conceptual recommendations are concerned regarding the advancement of the discussion of this topic, modifications can be done to the conceptual model. For instance, hypotheses that were not tested in this research could be tested. This means that the relationship between value co-destruction and supportive organizational climate could be tested as well as the relationship between supportive organizational climate and leadership support. It could also be suggested that addition constructs be added to the existing model or the same model and constructs be used for a different sector to see whether the same results could be replicated.

\section{References}

Anderson, J.C., \& Gerbing, D.W. (1988). Structural equation modeling in practice: A review and recommended two-step approach. Psychological bulletin, 103(3), 411-423. https://doi.org/10.1037/0033-2909.103.3.411

Bagozzi, R. \& Yi, Y., (2012). Specification, evaluation, and interpretation of structural equation models, Journal of the Academy of Marketing Science, 40(1), 8-34. https://doi.org/10.1007/s11747-011-0278-x

Chinomona, R \& Chinomona, E. (2013). The influence of employees' perceptions of organisational politics on turnover intentions in Zimbabwe's SME sector. South African Journal of Business Management, 44(2), 15-24. https://doi.org/10.4102/sajbm.v44i2.156

Claycomb, C., Dröge, C., \& Germain, R. (2001). Applied process knowledge and market performance: the moderating effect of environmental uncertainty, Journal of Knowledge Management, 5(3), 264-278. https://doi.org/10.1108/13673270110401239

Chuchu, T., Chiliya, N., \& Chinomona, R. (2018). The impact of servicescape and traveller perceived value on affective destination image: an airport retail services case. The Retail and Marketing Review, 14(1), 45-57.

Cunha, M. N. (2019). An investigative study of customer experience on customised customer contact services in OLisboa Hotels. African Journal of Hospitality, Tourism and Leisure, 8(5), 1-20.

Cunha, M. N. (2019). Organisational level antecedents of value co-destruction in hospitality industry: An investigation of the moderating role of employee attribution. African Journal of Hospitality, Tourism and Leisure, 8(4), 1-11.

Devereux, M. T., \& Gallarza, M. G. G. (2019). Social value co-creation: Insights from consumers, employees, and managers. In Corporate social responsibility: Concepts, methodologies, tools, and applications. 55-79. IGI Global. https://doi.org/ 10.4018/978-1-5225-6192-7.ch004

Echeverri, P., Salomonson, N., \& Åberg, A. (2012). Dealing with customer misbehaviour: Employees’ tactics, practical judgement and implicit knowledge. Marketing Theory, 12(4), 427-449.https://doi.org/10.1177/1470593112457741

Echeverri, P., \& Skålén, P. (2011). Co-creation and co-destruction: A practice-theory based study of interactive value formation. Marketing theory, 11(3), 351-373.https://doi.org/10.1177/1470593111408181 
Faed, A., \& Forbes, D. (2010). Impact of customer management system in improving customer retention: Optimisation of negative customer feedback. World Academy of Science, Engineering and Technology, 72(1), 171-175. https://doi.org/10.5281/zenodo.1077839

Field, A. (2013). Discovering statistics using IBM SPSS. 4th ed. London: Sage.

Fornell, C., \& Larcker, D. F. (1981). Evaluating structural equation models with unobservable variables and measurement error. Journal of marketing research, 18(1), 39-50. https://doi.org/10.2307/3151312

Foroudi, P., Yu, Q., Gupta, S., \& Foroudi, M. M. (2019). Enhancing university brand image and reputation through customer value co-creation behaviour. Technological Forecasting and Social Change, 138, 218-227. https://doi.org/10.1016/j.techfore.2018.09.006

Fraering, M., \& Minor, M.S. (2006). Sense of community: An exploratory study of US consumers of financial services. International Journal of Bank Marketing, 24(5), 284-306.https://doi.org/10.1108/02652320610681738

Franke, N., Keinz, P., \& Steger, C. J. (2016). Testing the value of customisation: when do customers really prefer products tailored to their preferences? Journal of marketing, 73(5), 103-121.https://doi.org/10.1509/jmkg.73.5.103

Frawley, A. (2014). Igniting Customer Connections: Fire Up Your Company's Growth by Multiplying Customer Experience \& Engagement. John Wiley \& Sons.

Gagnon, G. B., \& Roh, Y. S. (2016). The impact of customisation and reliability on customer satisfaction in the US lodging industry. Journal of Quality Assurance in Hospitality \& Tourism, 8(3), 60-78. https://doi.org/10.1080/15280080802080276

Ganesan-Lim, C., Russell-Bennett, R., \& Dagger, T. (2015). The impact of service contact type and demographic characteristics on service quality perceptions. Journal of services Marketing, 22(7), 550-561. https://doi.org/10.1108/08876040810909677

Gu, Y. D., \& Peng, J. S. (2010). The effect of organizational creative climate on employees' creative behavior: The moderating effect of creative self-efficacy. Nankai Business Review, 13(1), 30-41.https://doi.org/10.1016/j.jbusres.2018.04.001

Gujral, M., Rauzela, M., \& Chuchu, T. (2016). An Application of the Marketing Mix and Online Marketing as a Business Strategy for SMME Cafés in South Africa. Journal of Economics and Behavioral Studies, 8(3), 14-25.

Hayat, A., \& Afshari, L. (2020). Supportive organisational climate: a moderated mediation model of workplace bullying and employee well-being. Personnel Review, ahead of print. https://doi.org/10.1108/PR-06-2020-0407

Hoyer, W. D., Chandy, R., Dorotic, M., Krafft, M., \& Singh, S. S. (2010). Consumer cocreation in new product development. Journal of service research, 13(3), 283-296.https://doi.org/10.1177/1094670510375604

Hulland, J. (1999). Use of partial least squares (PLS) in strategic management research: a review of four recent studies. Strategic management journal, 20(2), 195-204. https://doi.org/10.1002/(SICI)1097-0266(199902)20:2<195::AID-SMJ13>3.0.CO;2-7

Iqbal, S., Ehsan, S., Rizwan, M., \& Noreen, M. (2014). The impact of organisational commitment, job satisfaction, job stress and leadership support on turnover intention in educational institutes. International Journal of Human Resource Studies, 4(2), 181-195.https://doi.org/10.5296/ijhrs.v4i2.5906

Järvi, H., Kähkönen, A. K., \& Torvinen, H. (2018). When value co-creation fails: Reasons that lead to value codestruction. Scandinavian Journal of Management, 34(1), 63-77.https://doi.org/10.1016/j.scaman.2018.01.002

Kerzner, H. (2018). Project management best practices: Achieving global excellence. John Wiley \& Sons.

Kirrane, M., Lennon, M., O’Connor, C., \& Fu, N. (2017). Linking perceived management support with employees' readiness for change: the mediating role of psychological capital. Journal of Change Management, 17(1), 47-66. https://doi.org/10.1080/14697017.2016.1214615

Lee, M.C. (2009). Predicting and explaining the adoption of online trading: An empirical study in Taiwan. Decision Support Systems, 47(2), 133-142. https://doi.org/10.1016/j.dss.2009.02.003

Luthans, F., Youssef, C. M., \& Avolio, B. J. (2007) Psychological capital. New York, NY: Oxford University Press.

Lysons, K. \& Farrington, B. (2012). Purchasing and supply chain management. Eighth edition. Pearson education limited. Harlow.

Plé, L. (2017). Why do we need research on value co-destruction?. Journal of Creating Value,3(2), 162169.https://doi.org/10.1177/2394964317726451

Martinko, M. J., Harvey, P., Sikora, D., \& Douglas, S. C. (2011). Perceptions of abusive supervision: The role of subordinates' attribution styles. The Leadership Quarterly, 22(4), 751-764. https://doi.org/10.1016/j.leaqua.2011.05.013

Maziriri, E.T., Rukuni, T.F., \& Chuchu, T. (2020). From selected multi-sensory dimensions to positive word of mouth: Data on what really drives generation $\mathrm{Z}$ consumers to be attached to quick service restaurants in Bloemfontein, South Africa? Data in Brief. 32(October). 1-8.https://doi.org/10.1016/j.dib.2020.106279

Norton, M. I., Mochon, D., \& Ariely, D. (2012). The IKEA effect: When labor leads to love. Journal of consumer psychology, 22(3), 453-460. https://doi.org/10.1016/j.jcps.2011.08.002

Pamacheche, R., Chinomona, R., \& Chuchu, T. (2016). Management's Commitment, Education and Ethics on Organisational Entrepreneurship: The Case of South African Non-Profit Organisations. Journal of Economics and Behavioral Studies, 8(4), 133-143.

Payne, A., \& Frow, P. (2013) A strategic framework for customer relationship management. Journal of Marketing 69, 167-176. https://doi.org/10.1509/jmkg.2005.69.4.167

Plé, L., \& Chumpitaz Cáceres, R. (2010). Not always co-creation: introducing interactional co-destruction of value in servicedominant logic. Journal of Services Marketing, 24(6), 430-437.https://doi.org/10.1108/08876041011072546

Read, B (2011). Top tips to build and keep customer loyalty with CRM. Customer Interactive Solution 27, 26-28. 
Van Doorn, J., Lemon, K. N., Mittal, V., Nass, S., Pick, D., Pirner, P., \& Verhoef, P. C. (2010). Customer engagement behavior: Theoretical foundations and research directions. Journal of service research, 13(3), 253-266. https://doi.org/10.1177/1094670510375599

Vargo, S. L., \& Lusch, R. F. (2008). Service-dominant logic: continuing the evolution. Journal of the Academy of marketing Science, 36(1), 1-10. https://doi.org/10.1007/s11747-007-0069-6

Yousefian, J., Akamavi, R., Jayawardhena, C., \& Khavari, L. (2011). Value Co-Creation and Value Co-Destruction in the Sport Service Sector: Is Customer Engagement Always Beneficial? University of Hull/ University of Tehran.

Zhao, J., Tao, J., \& Xiong, G. (2019). Online brand community climate, psychological capital, and customer value cocreation. Social Behavior and Personality: an international journal, 47(3), 1-14.https://doi.org/10.2224/sbp.7649

Zhou, M. (2015). Public environmental skepticism: A cross-national and multilevel analysis. International Sociology, 30(1), 61-85. https://doi.org/10.1177/0268580914558285

Publisher's Note: SSBFNET stays neutral with regard to jurisdictional claims in published maps and institutional affiliations.

\section{(c) (1)}

(C) 2021 by the authors. Licensee SSBFNET, Istanbul, Turkey. This article is an open access article distributed under the terms and conditions of the Creative Commons Attribution (CC BY) license (http://creativecommons.org/licenses/by/4.0/).

International Journal of Research in Business and Social Science (2147-4478) by SSBFNET is licensed under a Creative Commons Attribution 4.0 International License. 